\title{
IDENTIFIKASI STAKEHOLDER DAN ANALISIS AKTOR SERTA KELEMBAGAAN TERKAIT ISU PUBLIK PENGEMBANGAN KAWASAN PETERNAKAN KERBAU BERBASIS KEARIFAN LOKAL DI GAYO LUES
}

\author{
Abdullah Akhyar Nasution ${ }^{1}$, Iromi Ilham ${ }^{1}$, Teuku Kemal Fasya ${ }^{1}$ \\ ${ }^{1}$ Program Studi Antropologi, Fakultas Ilmu Sosial dan Ilmu Politik, Universitas \\ Malikussaleh
}

Korespondensi: abdullah.akhyar@unimal.ac.id

\begin{abstract}
Abstrak: Tradisi beternak kerbau saat ini masih dapat dijumpai di banyak daerah di nusantara, namun secara kualitas dan kuantitas sudah jauh berkurang, termasuk tradisi uwer (beternak) kerbau yang dipraktekkan oleh masyarakat Gayo Lues. Salah satu penyebab adalah kurangnya perhatian stakeholder setempat terhadap permasalahan ini. Padahal, praktek uwer tidak hanya berpotensi mengembangkan kesejahteraan ekonomi masyarakat, namun juga sarat dengan nilai-nilai kearifan lokal. Jika tidak dilakukan proteksi, tidak menutup kemungkinan kerbau akan hilang dalam budaya kehidupan Gayo. Kondisi ini menjadi dasar bagi peneliti untuk mengkaji tentang identifikasi stakeholder dan analisis aktor serta kelembagaan terkait pengembangan kawasan peternakan yang berbasis keraifan lokal di Gayo Lues. Lebih lanjut, penelitian ini juga membahas tentang bagaimana para aktor dan lembaga terkait dengan pengelolaan dan isu pengembangan peternakan di kawasan tersebut. Penelitian ini menggunakan studi etnografi dan metode analisis jaringan. Pengumpulan data dilakukan dengan observasi, wawancara dan Focuss Group Discussion (FGD). Penelitian ini menghasilkan beberapa diskusi, yaitu: Pertama, banyak aktor dan lembaga yang terlibat dalam usaha pengembangan peternakan kerbau di Gayo Lues, namun kurangnya sinergitas dan kerjasama antar aktor berimplikasi pada degradasi kebudayaan peternakan kerbau yang berbasis kearifan lokal; kedua, kurangnya stategi yang dimiliki oleh pemangku kebijakan berimplikasi pada kurang minatnya masyarakat untuk melanjutkan tradisi uwer saban hari. Seharusnya banyak potensi yang bisa dilihat, dikembangkan dan dimanfaatkan terkait praktek peternakan kerbau di Gayo Lues; dan ketiga, sistem sosial yang diperankan oleh pemerintah, peternak kerbau, tokoh adat, juga toke kerbau harus dimaksimalkan sehingga bisa mencegah terjadinya economic inequality dan cultural insecurity.
\end{abstract}

Kata Kunci: Stakeholder, Aktor, Peternakan Kerbau, Pengembangan Kawasan, Kearifan Lokal 


\section{A. Pendahuluan}

Sampai hari ini, isu pangan masih menjadi persoalan di banyak negara di dunia. Pada dasarnya ada banyak isu sekitar pangan yang menjadi fokus permasalahan. Ada negara yang mengalami kesulitan terkait ketersediaan pangan, ada juga yang mengalami masalah distribusi pangan, ada negara yang mengalami masalah dalam aspek kemandirian pangan dan ada juga yang mengalami masalah dalam mengontrol harga pangan. Tidak hanya itu, ada juga negara yang mengalami sebagian atau semua masalah tersebut secara bersamaan.

Begitu pentingnya isu pangan, maka hampir di setiap era ada saja tokoh yang memberi perhatian tentang pangan. Pada abad 18 saja, Robert Malthus yang merupakan teolog juga ahli demografi dalam sebuah tulisannya yang berjudul $A n$ Essay on the Principle of Population (1798) memprediksi tentang kepunahan manusia. Kepunahan tersebut dalam pandangannya terjadi karena ketersediaan pangan yang tumbuh lebih lambat dibandingkan dengan pertumbuhan jumlah penduduk. Banyak kritik atas pemikiran tersebut, diantara mereka yang mengkritik mengatakan bahwa asumsi Malthus hanya mungkin terjadi saat manusia tidak mengembangkan pemikirannya karena pengembangan pemikiran yang terus menerus akan mendorong lahirnya teknologi yang bisa digunakan untuk meningkatkan produksi pangan. e

Di Indonesia sendiri, persoalan pangan hampir tidak pernah selesai. Dimulai dari masalah ketersediaan, distribusi, akses harga, dan diversifikasi pangan. Jika di awal berdirinya republik ini masalah utama adalah ketersediaan pangan, (baca Leo, 2013) maka di era orde baru masalah pangan lebih banyak ke upaya unirformitas ragam pangan, pengontrolan harga pangan dan upaya kooptasi negara terhadap petani sebagai produsen pangan (Anggreini, 2013). Sementara itu, di era reformasi, kerinduan akan diversifikasi pangan, swasembada dan jaminan ketersediaan bahan pangan menjadi isu kembali. Sekalipun demikian, isu rekayasa pangan juga mulai ikut dipermasalahkan.

Terlepas dari itu semua, semangat desentralisasi sebagai keturunan langsung reformasi juga ikut memberi pengaruh pada potensi lokal yang ada termasuk potensi penyediaan pangan. Hanya saja semangat sentralisasi pengelolaan pangan masih lebih besar ketimbang implementasi kewenangan untuk 
mendelegasikan pengelolaan pangan ke daerah. Ini dapat dilihat dari proses pengadaan bahan pangan secara nasional yang masih didominasi pusat yang ujungujungnya berbau kolutif. Lihat saja pembukaan keran impor daging, gula, garam yang semuanya terindikasi koruptif (Amanda, 2018).

Sejauh ini, hasil akhir dari pengelolaan pangan secara nasional tampaknya belum melahirkan pola baku dan dampak yang signifikan pada kesejahteraan masyarakat di daerah. Pengaturan atau regulasi pangan juga masih terkesan tumpang tindih (Zuraya, 2016). Praktek opersional, pengelolaan pangan juga sering dilakukan secara sektoral oleh masing-masing kementerian sehingga hasil akhirnya tidak maksimal. Indikasi ketidakmasimalan pengelolaan pangan kita adalah ketidakberdayaan negara dalam mengontrol harga pangan nasional, kelaparan yang terjadi di beberapa daerah (lihat Affan, 2018) hingga tergerusnya kearifan lokal pengelolaan pangan di beberapa daerah dan lainnya.

Saat ini, satu hal penting yang harusnya ikut menjadi perhatian banyak pihak adalah bagaimana peluang setiap daerah yang dengan kewenangannya bisa melahirkan regulasi pangan yang memenuhi sifat-sifat regulasi yang baik. Tidak hanya bersifat "problem solving" dan antisipatif, regulasi daerah terkait pangan juga selayaknya mengakomodir kearifan dan praktek masayarakat lokal yang berhubungan langsung dengan penyediaan pangan, baik pangan berunsur karbohidrat, protein dan unsur lainnya.

Salah satu pratek sistem penyediaan pangan lokal yang juga banyak ditemukan di masyarakat Indonesia adalah peternakan dengan ragam polanya. Jenis hewan yang dipeliharan oleh masyarakat Indonesia secara tradisional cukup beragam mulia dari, kerbau, sapi, kuda, kambing, babi, ayam dan lainnya. Jika dalam dasawarsa terakhir kita heboh dengan polemik impor daging, maka membahas eksistensi tradisi beternak untuk menghasil daging termasuk daging kerbau menjadi sangat menarik. Kemenarikan tersebut dapat dilihat dari fakta bahwa pengalaman banyak msayarakat yang terikat dengan budayanya dalam memelihara kerbau ternyata tidak sepenuhnya didukung untuk memenuhi kebutuhan dalam negeri. Dalam daswarsa terakhir kebutuhan daging kerbau mayoritas dipenuhi dengan cara impor. Untuk tahun 2018 saja pemerintah telah membuka kran impor 
daging kerbau sebesar 100.000 ton daging kerbau. Jumlah ini jauh lebih besar dari impor tahun 2017 yang hanya 55.000 ton (Kontan.co.id, 2018).

Tradisi beternak kerbau saat ini memang masih dapat dijumpai di banyak daerah di nusantara, namun secara kualitas dan kuantitas sudah jauh berkurang. Masyarakat Gayo di kabupaten gayo Lues adalah salah satu masyarakat yang masih mempraktekkan peternakan tradisional. Namun dalam prakteknya mereka juga telah melahirnya varian pola peternakan kerbau sebagai upaya adaptasi atas perubahan kondisi sosial, budaya, ekonomi dan politik. Sistem peternakan kerbau secara tradisional disebut oleh masyarakat Gayo dengan sebutan uwer untuk kata bendanya, sedangkan kata jamaknya adalah pureweren.

Saat ini, memberi perhatian pada bagaimana isu ketersediaan daging di tingkat lokal bisa dilihat sebagai hal yang positif. Semangat ini akan bisa memotivasi pengembangan uwer melalui sebuah kebijakan publik. Selain peluang untuk itu terbuka lebar, kesempatan itu juga akan bisa memproteksi tergerusnya nilai kerbau dari budaya orang Gayo.

Berdasarakan gambaran fenomena di atas, maka dirasa perlu melakukan identifikasi stakeholders personal maupun kelembagaan serta peranannya dalam isu pengembangan kawasan peternakan kerbau di Gayo Lues. Bila disederhanakan, maka penelitian ini dilakukan untuk : 1) mengetahui siapa serta lembaga mana saja yang secara langsung dan tidak langsung memiliki keterkaatan dengan isu pengembangan kawasan peternakan kerbau dalam hubungannya dengan pemenuhan kebutuhan protein hewani di Kabupaten Gayo Lues; 2) Apa dan bagaimana aktor individu dan lembaga memainkan perannya terkait isu pengembangan kawasan peternakan kerbau di Gayo Lues.

Secara umum, tujuan dari penelitian ini adalah untuk membantu pemerintah daerah dalam membangun strategi pelibatan stakeholder untuk menjadikan isu pengembangan kerbau sebagai isu publik yang memerlukan regulasi khusus. Dengan kata lain, manfaat penelitian ini akan bisa digunakan untuk membangun kesadaran elemen masyarakat yang ada untuk terlibat secara bersama-sama guna mendorong pemerintah daerah melahirkan regulasi tentang uwer. Regulasi tersebut harusnya lahir sebagai upaya mengatasi permasalah publik. Dalam konteks ini, permasalahan publik yang juga ditemukan di Kabupaten Gayo Lues adalah 
keterbatasan pasokan daging kerbau. Sementara itu, isu publiknya adalah secara kultural, Orang Gayo memiliki sistem yang teruji dalam menyediakan pasokan daging kerbau namun saat otonomi daerah diterapkan sistem tersebut malah tidak berkontribusi pada kemampuan daerah untuk menyediakan kebutuhan daging secara lokal apalagi mendukung peningkatan kesejahteraan masyarakat.

\section{B. Metode Penelitian}

Penelitian ini dilakukan di Kabupaten Gayo Lues. Salah satu alasan mengapa kabupaten ini dipilih adalah sampai saat ini hanya Kabupaten Gayo Lues yang masih ditemukan tradisi beternak dengan sistem lepas liar. Di saat bersamaan, pemerintah Kabupaten gayo Lues juga lagi gencar-gencarnya mengkampanyekan pengembangan sektor peternakan.

Jenis penelitian ini adalah penelitan terapan atau applied research. Untuk memudahklan operasional, maka paradigma yang dipakai adalah paradigma kritis. Dalam prkatek di lapangan, penelitian ini sepenuhnya menggunakan pendekatan kualitatif yang berbasis etnografi dan metode analisis jaringan sosial. sementara dalam mengumpulkan data, peneliti menggunakan metode observasi partisipatif (lihat Kawulich, 2005), wawancara mendalam, dan FGD (Focus Group Discussion). Observasi dilakukan untuk mengamati langsung bagaimana kondisi eksisting pola peruweran yang dipraktekkan masyarakat Gayo, sementara wawancara mendalam adalah teknik yang lazim digunakan sebagai bagian dari metode etnografi (lihat Spradley, 2007). Mengingat keragaman data yang diperlukan secara tematik serta tingkat kedalaman informasi yang diperkirakan hendak diperoleh, maka dalam penelitian diputuskan ada dua kelompok informan yang hendak diwawancarai, yaitu Informan Kunci/ Key Informan dan Informan pendukung/ Biasa.

Focuss Group Discussion adalah sebuah teknik partisipatif yang muncul seiring dengan tumbuhnya gerakan untuk melibatkan masyarakat dalam proses pembangunan secara partisipatif. Krueger and Casey menuliskan bahwa focus grup adalah "carefully planned series of discussions designed to obtain perceptions on a defined area of interest in a permissive, non-threatening environment" (Krueger and Casey, 2005). Alasan mengapa FGD telah menjadi bagian umum dari teknik pengumpulan data penelitian karena teknik ini bisa menggali lebih dalam sebuah 
tema yang dibahas dalam penelitian (lebih lanjut baca Borrows, 2000). Dengan mengombinasikan teknik ORID (Objective, Reflective, Interpretative, Decisional) pada pelaksanan FGD, maka peneliti bisa membangun sebuah analisis jaringan awal atas stakeholder yang teridentifikasi dari observasi dan wawancara serta mendalami perannya.

\section{Teknik Analisa Data}

Data-data yang diperoleh melalui observasi partisipasi dan wawancara mendalam diolah secara etnografis dengan model "Multidemionsional Analysis Scaling" atau disingkat MDS. Model ini dipakai untuk melahirkan sebuah analisis jaring laba-laba. Sementara itu, data dan informasi yang didapat saat FGD sepenuhnya juga sudah melalui tahapan analisis sehingga peneliti hanya merangkum hasil FGD dengan lebih sistematis.

Proses FGD dikatakan sebagai bagian dari proses analisis karena data yang dikumpulkan melalui observasi dan wawancara medalam disusun sebagai bahan dan atau agenda tema diskusi pada FGD. Dengan demikian, hasil FGD tentang berbagai tema yang diajukan bisa menjadi data baru dan analisa tentang kejelasan personal dan kelembagaan yang bertindak sebagai stakeholder bagi kebijakan pengembangan kawasan peternakan kerbau berbasis kearifan lokal di Gayo Lues. Pada akhirnya, semua temuan dan hasil analisis dituangkan ke dalam tulisan dengan mengadopsi prinsip penulisan etnografi yang baik.

\section{Hasil dan Pembahasa}

\section{Mengenal Masyarakat Gayo dan Tradisi Beternak Kerbau}

Kabupaten Gayo Lues adalah salah satu kabupaten di Provinsi Aceh yang merupakan pemekaran dari Kabupaten Aceh Tenggara dengan Dasar Hukum UU No.4 Tahun 2002 pada tanggal 10 April 2002. Kabupaten ini berada di gugusan pegunungan Bukit Barisan. Sebagian besar wilayahnya merupakan areal Taman Nasional Gunung Leuser yang telah dicanangkan sebagai warisan dunia. Pada mulanya daerah Gayo dan Alas membentuk pemerintahan sendiri terpisah dari Kabupaten Aceh Tengah. Oleh karena itu terbentuklah Kabupaten Aceh Tenggara (UU No. 4/1974). Namun karena daerah Gayo mengalami kesulitan, mereka pun membentuk kabupaten tersendiri yang dinamakan Kabupaten Gayo Lues (UU No. 
4/2002) dengan ibukota kabupaten Blangkeujren.

Berdasarkan Undang-Undang Nomor 4 Tahun 2002 Luas Wilayah Kabupaten Gayo Lues adalah 571.990,90 Ha, sedangkan menurut GIS luas wilayah Kabupaten Gayo Lues adalah 554.991,06 Ha atau 10\% dari luas Provinsi Aceh. Penduduk Kabupaten Gayo Lues pada umumnya merupakan suku Gayo, Minang, Aceh, Alas, Jawa, Batak dan yang lainnya. Perkiraan jumlah penduduk Kabupaten Gayo Lues pada pertengahan tahun 2013 berjumlah 84.511 jiwa yang terdiri dari 41.957 lakilaki dan 42.554 perempuan dengan rasio jenis kelamin 99.

Disadari atau tidak, sub sektor peternakan memiliki peranan yang strategis dalam kehidupan perekonomian dan pembangunan sumberdaya manusia daerah. Peranan ini dapat dilihat dari fungsi produk peternakan sebagai penyedia protein hewani yang penting bagi pertumbuhan dan perkembangan tubuh manusia. Oleh karenanya tidak mengherankan bila produk-produk peternakan disebut sebagai bahan "pembangun" dalam kehidupan ini. Selain itu, secara hipotetis, peningkatan kesejahteraan masyarakat akan diikuti dengan peningkatan konsumsi produkproduk peternakan, yang pada akhirnya turut menggerakan perekonomian pada sub sektor peternakan.

Harus diakui bahwa sampai saat ini sangat sedikit sekali literature yang membahsa tentang uwer secara spesifik. Penelusuran di dunia maya hanya memunculkan beberapa publikasi yang menggunakan kata uwer. Hanya saja publikasi tersebut tidak menjelaskan dengan detail apa dan bagaimana uwer. Dari hasil wawancara dan penelusuran publikasi yang ada diketahui bahwa Uwer adalah sistem pertenakan kerbau yang dipraktekkan oleh masyarakat Gayo di Datraan Tinggi Gayo. Saat ini Dataran Tinggi Gayo secara administratif terbentuk atas 3 kabupaten, yaitu; Kabupaten Aceh tengah, Bener Meriah, Gayo Lues. Ketiga kabupaten tersebut juga merupakan daerah Culture Area masyarakat Gayo. Pada awalnya tradisi uwer dipraktekkan oleh ketiga mayarakat Gayo di tiga kabupaten tersebut.

Sebagaimana dijelaskan, uwer sendiri adalah kosa kata Gayo yang artinya kandang. Sekalipun berarti kandang, dalam praktek original-nya dahulu peternakan kerbau di Gayo tidaklah memakai kandang. Kandang saat itu hanya terdiri dari sebuah bangunan yang menjadi tempat peternak memberi mineral berupa garam 
pada gerombolan ternaknya. Kandang dalam tradisi ternak kerbau di Gayo memang tidak dipakai sebagai tempat memelihara ternak sebab model pemeliharaan yang sejak dulu dipraktekkan adalah dengan melepaskan kerbau di alam atau hutan sehingga polanya adalah lepas liar. Untuk menjamin agar kerbau yang dilepaskan mau kembali ke lokasi awal dimana ternak tersebut dilepaskan, biasanya pemilik melalui pawang akan memberikan garam kepada kerbau secara periodik. Hasil wawancara dengan pawang, jadwal pemberian garam bisa sebulan sekali, tiga bulan sekali atau waktu lainnya sesuai pengetahuan sang pawang. Posisi pawang dalam sistem uwer lepas liar memang sangat sentral. Pawang ini, selain bertanggung jawab melepas, pawang juga merupakan orang yang memiliki kemampuan untuk membangun ikatan dengan gerombolan ternak.

Tidak itu saja, dalam sistem pengetahuan lokal, pawang juga dianggap sebagai orang yang memiliki kemampuan gaib/ magis dalam mengontrol keberadaan gerombolan kerbau yang menjadi tanggungjawabnya. Hal penting lainnya dari peran pawang juga dapat dilihat saat mengidentifikasi mana kerbau yang akan dipanen. Saat pemilik kerbau memerlukan kerbau untuk dijual atau dikonsumsi, kehadiran pawang untuk menangkap kerbau liar yang dimilikinya sangat dibutuhkan.

Berdasarkan literature dan hasil wawancara penulis dengan seorang pawang yang berhasil dijumpai, diketahui bahwa kehidupan orang Gayo dahulunya tidak akan pernah jauh dari kerbau. Pawang yang dijumpai juga menjelaskan bahwa sejak kecil ia melihat kehidupan orang Gayo bersandar pada peternakan kerbau dalam semua aspek. Mau menikah, jual kerbau dan pakai kerbau. Mau bangun rumah orang Gayo jual kerbau. Mau menyekolahkan anak, orang Gayo juga jual kerbau. Saat akan menunaikan ibadah haji-pun orang Gayo juga akan jual kerbau. Pernyataan singkat ini jelas membantu kami memahami bagaimana posisi kerbau di masyarakat Gayo. Bila dahulunya uwer dengan model lepas liar itu masih dapat dijumpai di hampir semua kabupaten di dataran Tinggi Gayo termasuk di Kabupaten Bener Meriah, Aceh Tengah dan gayo Lues. Namun demikian, saat ini praktek uwer model lepas liar ini hanya bisa dijumpai di Kabupaten Gayo Lues. Dari beberapa kecamatan di Gayo Lues, Uwer lepas liar dapat dijumpai di Kecamatan Terangun dan sebagian kecil di Rikit Gaib. 
Sebagaimana disebutkan, peternakan kerbau yang dipraktekkan sebagaian masyarakat di Kecamatan Terangun dan Rikit Gaib, berbeda polanya dengan peternakan di wilayah lain. Para pemilik kerbau biasanya tidak mencari makanan kerbau, tidak membuat kandang, serta tidak setiap hari melihat kerbau miliknya. Ternak dilepaskan liar di alam (hutan) dan jika ada keperluan tertentu barulah kerbau-kerbau tersebut "dipanggil" oleh pawang untuk dikumpulkan agar bisa dijual atau dikonsumsi. Setiap kelompok hewan ternak yang dilepas liarkan di hutan ditanggungjawabi oleh seorang "pawang". Kerbau-kerbau liar tersebut hanya akan dikumpulkan saat akan "dipanen". Proses mengumpulkan hewan ternak yang liar tersebut biasanya juga diikuti dengan ritual mistis, seperti membakar kemenyan, rapalan mantra dan membuat selengsung. Kerbau-kerbau yang telah bertahun-tahun dilepas itu bisa dipanggil kembali oleh sang pawang.

Dahulu, gerombolan kerbau liar yang diternak dengan menggunakan jasa "Pawang" juga digunakan untuk membantu mengolah sawah. Puluhan atau ratusan ekor kerbau dalam satu gerombolan di saat musim tanam akan dimulai oleh pawang akan diarahkan ke lahan persawahan. Di areal persawahan tersebut, kerbau-kerbau akan dipandu untuk menginjak-injak sawah yang sebelumnya sudha digenangi air. Akibat pijakan puluhan atau ratusna kerbau, lahan sawah akan menjadi lunak sebagaimana lahan yang dibajak. Jika dianggak sudah layak untuk ditanami, maka gerombolan kerbau liar tersebut akan dipandu untuk kembali ke hutan.

Dalam perkembangan saat ini, praktek uwer telah mengalami modifikasi. Oleh Nasution (2019) disebutkan setidaknya ada 4 sistem $u$ wer yang dapat dijumpai di Dataran tinggi Gayo, yaitu :

a. Uwer dengan pola lepas liar

Dengan sistem ini ternak kerbau dilepasliarkan di satu kawasan hutan dengan ritual tertentu dengan titik pelepasan ditandai dengan adanya pondok/kandang. Pondok/ kandang tersebut biasanya berfungsi juga sebgaia tempat untuk memberi kerbau unsur mineral berupa air garam dalam kurun waktu tertentu. Namun yang kutanggap untuk mengumpulkan kerbau yang dilepasliarkan tersebut tidaklah harus di pondok tapi bisa di kawasan lain dalam wilayah hutan tergantung keputusan sang pawang.

b. Uwer dengan pola lepas siang dan malam dikandangkan 
Sistem ini relatif sama dengan uwer lepas liar, hanya saja kawanan ternak saat sore hari akan kembali dengan sendirinya ke kandang yang telah dipersiapkan. Dengan sistem ini ternak kerbau dilepaskan di satu kawasan tertentu pada saat siang hari. Namun pada saat malam hari kawanan ternak kerbau tersebut akan masuk ke kandang yang lokasinya berada dalam satu lahan yang dipagar dengan ciri adanya sebuah pondok untuk tempat berkumpul kerbau. Uwer versi ini masih memberi ruang kerbau untuk menjelajah karena pada waktu tertentu kawanan kerbau juga kerap tidak pulang karena mencari makan di wilayah yang relatif jauh namun akan kembali ke kandang.

c. Uwer dengan pola kandang luas

Peternakan ini ditandai dengan adanya pelepasan hewan ternak dalam satu lahan. Agar tidakan merusa lading atau lahan orang lain, lahan tempat beternak kerbau tersebut dibuat agar dengan beragam bahan. Ada pagar yang dibuat dari kayu, kawat dan ada kalanya hanya berbahan bambo. Ternak kerbau ditempatkan dalam kawasan yang telah dipagar tersebut dengan disediakan pondok berteduh. Pada uwer versi ini, kawanan ternak tidak dilepaskan sehingga sang pemilik atau penjaga harus menyediakan pakan buat kawanan ternak setiap hari.

d. Uwer dengan pola kandang intensif.

Pola peternak ini biasanya ditandai penggunaan kandang batray dimana disetiap kandang akan ada hewan ternak. Tujuan dari ternak ini biasanya hanya menggemukan untuk dipanen dagingnya atau dijual dalam kurun waktu tertentu. Pemilik atau penjaga bertanggung jawab untuk mencari dan memberi pakan pada ternak yang dikandangkan. Ciri lain dari hewan yang dipelihara model ini bisanya hidung kerbaunya telah dilubangi untuk memudahkan mengendalikannya. 


\section{Identifikasi Stakeholder dan Analisis Aktor}

Dalam catatan sejarah, sistem ekonomi yang diserahkan sepenuhnya kepada pasar terlihat tidak selalu berjalan efektif dan efisien. Perilaku aktor-aktor yang terlibat di dalamnya seringkali mengarah pada hal-hal yang sesuai dengan kepentingannya dan mekanisme pasar pun sering kali gagal dalam mengoreksinya. Karena itu, tidak ada pasar yang efisien dalam hal alokasi dan penggunaan sumberdaya ekonomis, selama keseimbangan informasi untuk seluruh aktor yang terlibat tidak tercapai. Jika semuanya dikendalikan oleh system pasar, maka akan berdampak pada persoalan kemiskinan, pengangguran, serta yang paling parah adalah disparitas pendapatan di antara petani. Permasalahan ini tidak hanya bersifat persoalan ekonomi, tetapi juga menyangkut struktur politik, nilai budaya dan nilai sosial. Karena itu, penting kiranya untuk menelusuri aktor-aktor yang terlibat aktif dalam hal peternakan kerbau di Gayo Lues.

Dari kajian lapangan didapatkan beberapa aktor yang terlibat aktif dalam sistem peternakan kerbau, yaitu sebagai berikut:

\section{a) Toke Kerbau}

Toke (agen) merupakan salah satu aktor yang berperan untuk melakukan transaksi jual beli dan lain lain. Dalam proses pemasaran ternak ada beberapa tahap yang dilakukan yaitu :

a. Peternak berinteraksi dengan toke atau pedagang untuk melakukan transaksi.

b. Toke atau pedagang mencermati dan menaksir berat dan atau kandungan daging ternak.

c. Toke dan pedagang menawarkan harga kepada peternak.

d. Terjadi kesepakatan harga antara penjual dan pembeli.

e. Kemudian, ternak dibawa keluar pasar dengan dua tujuan untuk dijual kembali atau dipelihara oleh peternak. (Madarisa, 2012 : 435 )

Menurut Mukmin, selaku toke koro (kerbau) mengatakan bahwa :

"Saya sering melakukan transaksi baik itu jual maupun beli hal itu saya lakukan ketika ada yang membutuhkan atau ada yang menghubungi saya untuk mencari hewan seperti kerbau, sapi dll, kalo melestarikan atau mengembangkan ternak saya rasa tidak ada yang dapat dilakukan toke karna 
toke salah satu tujuannya yaitu mendapatkan keuntungan, itu kembali lagi kepada si pembeli apakah si pembeli akan merawat atau memotong hewan tersebut, akan tetapi biasanya kami membeli ternak apalagi ternak besar seperti kerbau di waktu- waktu tertentu saja karena hewan tersebut jika ingin dipotong pastinya digunakan di hari- hari besar seperti haji, pernikahan atau untuk persembahan dan lain- lain".

Dalam pengakuannya, ia berperan sebagai mediator dalam menghubungkan antara penjual dengan pihak pembeli. Toke tidak berperan sebagai petani, yang dalam hal ini merawat kerbau dari kecil, lalu ketika sudah bisa dikonsumsi baru kemudian dijual. Di sisi yang lain, Jamaludin, selaku toke koro juga mengatakan bahwa:

"Saya sering berinteraksi dengan peternak kerbau karna banyak teman teman saya yang mempunyai ternak mereka sangat mempercayai saya dalam urusan jual beli atau yang lainnya, karena link saya banyak di mana - mana diakibatkan pergaulan saya yang luas mengakibatkan temen - temen saya lebih mau mempercayai saya dalam urusan jual beli.

Dari hasil wawancara di atas dapat juga dijelaskan bahwa intensitas membangun komunikasi dengan banyak orang akan semakin menambah peluang membangun jaringan yang tentu saja berimplikasi pada keuntungan ekonomi. Seorang toke harus memiliki jaringan sosial yang luas, sehingga logika ekonomi menjadi terbukti, di mana semakin banyak relasi yang dimiliki, maka kemungkinan untuk meningkatkan keuntungan semakin terbuka lebar.

Namun ada juga toke yang berpikir bahwa memasok daging kerbau untuk wilayah sendiri itu lebih penting ketimbang hanya berpikir masalah ekonomi, misalnya apa yang disampaikan Berlian, yang juga berprofesi sebagai toke koro berikut ini patut juga dicermati:

"Hal yang saya lakukan tidak jauh juga dengan toke koro yang lain juga pastinya kami akan melakukan penjualan dan pembelian kepada para peternak akan tetapi hal yang saya lakukan salah satunya untuk melestarikan kerbau yaitu menjual di dalam daerah saja tanpa menjual diluar daerah, dengan menjual keluar daerah pastinya akan membuat jumlah ternak berkurang dan tidak dapat dikembangkan dengan begitu sangat mengurangi jumlah ternak dalam daerah itu sendiri ini adalah salah satu cara saya agar mengurangi resiko agar tidak berkurangnya jumlah ternak."

Dari hasil wawancara di atas, dapat diambil kesimpulan bahwa toke koro ini juga melakukan penjualan dan pembelian, akan tetapi salah satu cara dia untuk 
melestarikan kerbau yaitu dengan mencegah atau tidak melakukan penjualan keluar daerah agar tidak mengurangi jumlah ternak yang ada didaerah itu sendiri, Dari hal yang lakukan toke kore mereka memang melakukan penjualan dan pembelian kepada para peternak karena tugas seorang toke (agen) salah satunya atau tujuannya mendapatkan keuntungan, dampaknya yaitu dengan melihat keuntungan saja mereka dapat menjual keluar daerah yang mengakibatkan berkurangnya jumlah ternak yang ada di daerah.

\section{b) Tokoh Masyarakat / Pemerhati Budaya}

Tokoh masyarakat adalah orang-orang yang memiliki pengaruh di masyarakat, baik tokoh masyarakat yang dipiih secara resmi maupun tidak. Secara kultural, praktek uwer adalah bentuk kebudayaan yang hidup dalam masyarakat Gayo Lues, di mana praktek ini juga menjadi salah satu sitem mata pencaharian yang hidup dalam masyarakat. Secara tidak langsung, tentu saja pengetahuan mengenai uwer diwariskan dari generasi ke generasi sebagai salah satu upaya untuk bertahan hidup. Karena itu, keterlibatan tokoh masyarakat dalam hal melestarikan budaya menjadi penting, serta peran yang dimainkan juga seperti apa. Menurut Abu bakar, tokoh masyarakat setempat mengatakan bahwa:

"Dilihat dari tradisi masyarakat kita kerbau merupakan hewan dari zaman dahulu yang dipakai untuk segala acara tradisi yang dilakukan masyarakat, dengan begitu saya selaku sebagai seseorang yang dipercaya oleh masyarakat pastinya harus tetap menjaga agar tidak punahnya hewan tersebut dan masih dilestarikan dengan cara mendukung usaha ternak yang mereka lakukan, karena apa hewan ini adalah hewan yang digunakan dengan jangka panjang, artinya dapat digunakan untuk kebutuhan mendesak dan dapat dijual di waktu- waktu mendesak, dengan begitu ekonomi masyarakat lebih membaik. Hal yang dapat saya lakukan hanyalah mendukung masyarakat.

Hasil wawancara diatas membuktikan bahwa salah satu hal yang dapat dilakukan oleh tokoh adat yaitu mendukung masyarakat dalam mengembangkan ternak kerbau karena keberadaan kerbau sangat penting untuk perhelatan adat di masyarakat. Dalam tradisi masyarakat Gayo, kerbau adalah hewan yang sangat krusial, baik secara fungsi maupun simbol bagi tradisi adat. Sebagaimana yang telah dijelaskan sebelumnya, kerbau dikonsumsi dagingnya bukan saja pada saat perayaan hari-hari besar Islam, namun juga ketika ada acara-acara besar yang dilaksanakan oleh warga, semisal pesta pernikahan. Bahkan kerbau juga menjadi 
"sesembahan" dalam upacara tradisi, seperti yang dikatakan oleh Alimuddin, tokoh masyarakat setempat sebagai berikut:

"kerbau memang ternak dari zaman dahulu yang sudah sangat berhubungan dengan masyarakat kita sendiri, karena ternak ini merupakan ternak yang dulunya sangat dibanggakan masyarakat kita sendiri, baik itu sebagai kebutuhan masyarakat dan ada yang memang memeliharanya itu hobi mereka akan tetapi dari dulu kerbau ini sangat bergantunggan bagi masyarakat apa pun acara yang dilaksanakan. contohnya dalam mengadakan tradisi seperti memperingati hari sungai pastinya kita menggunakan kerbau untuk persembahannya, ya saya sebagai orang yang lebih mengerti tentang adat dikampung pastinya mengigatkan masyarakat agar ingat dan tidak lupa.

Oleh karena itu, penting kiranya keberadaan tokoh adat atau kelembagaan adat setempat untuk melakukan transformasi pengetahun guna pelestarian sistem ternak kerbau di wilayah Gayo Lues agar tidak punah. Tentu saja, tokoh adat setempat memiliki pengetahuan lebih ketimbang masyarakat biasa. Sebagai individu yang berpengaruh dan memiliki wawasan lebih tentang adat, para tokoh bisa memainkan perannya dalam hal merawat tradisi. Sebagaimana yang disampaikan Sabtuddin sebagai berikut:

"Sebagai seseorang yang berpengaruh di masyarakat atau kami yang lebih memiliki wawasan yang lebih dari masyarakat lain, atau orang yang menjadi panutan dimasyarakat, peran yang dilakukan dalam mendukung ternak kerbau ya dengan cara mendukung juga dan mengigatkan masyarakat agar tidak lupa dengan tradisi masyarakat sendiri karena masyarakat di Gayo Lues memang ada hari-hari yang diperingati sebagai hari tawar kampung yang menggunakan hewan ternak kerbau sebagi persembahan atau dipotong ramerame dengan dana atau iuran yang di kutip oleh masyarakat kampung untuk membelinya.

Bagi warga setempat, keberadaan kerbau juga menjadi symbol. Dalam hal ini symbol persatuan, di mana setiap ada perhelatan acara kenduri, masyarakat sekitar mau urun dana untuk membeli kerbau yang bisa disembelih pada saat acara sebagaimana yang disampaikan di atas. Ini menjadi bentuk transformasi pengetahuan guna pelestarian tradisi agar tidak hilang. 


\section{c) Tokoh Politik}

Aktor lainnya yang berpengaruh terhadap pelestarian hewan ternak kerbau adalah tokoh politik. Mereka merupakan orang yang berkecimpung di bidang politik atau pemerintahan yang mempunyai kekuasaan dalam masyarakat antara lain sebagai pengambil keputusan atas sebuah kebijakan. Misalnya, apa yang dilakukan oleh Ali Husin, S. Sos, Ketua DPRK Kabupaten Gayo Lues, yaitu dengan meningkatkan motivasi bagi peternak kerbau untuk tetap menjalankan profesinya sebagai petani, meskipun ia juga memiliki profesi lain sebagai sumber penghidupan. Ia mengatakan bahwa:

"Saya sudah lama juga duduk di kursi DPRK dan mengenai isu yang terkait pada ternak kerbau memang kita ketahui kerbau merupakan hewan dari zaman dahulu yang sangat dekat dengan tradisi masyarakat kita sendiri akan tetapi dari perubahan zaman semakin maju hal ini dapat dilihat hilang dengan seketika banyak masyarakat kita yang sudah meninggalkan pekerjaan peternakan menjadi petani atau lain. Itu merupakan perubahan semakin berkembangnya zaman banyak yang sudah ditinggalkan, akan tetapi saya mendukung para peternak dengan menggerakan hati mereka untuk memperbaiki mutu dengan cara kami memberikan obat gratis suntik kepada masyarakat".

Dukungan dari pemerintahan sangat membantu masyarakat dalam hal pengembangan produksi hewan ternak kerbau. Ibnu Hasim, S. Sos, selaku wakil DPRK Kabupaten Gayo Lues juga mengatakan bahwa:

"Masyarakat kita apalagi gayo lues salah satu pendapatan masyarakat nya selain pertanian salah satunya adalah peternakan, saya sangat mendukung perekonomian masyarakat Gayo Lues baik di bidang pertanian, perternakan dan lain - lainnya, kami dari dinas hanya dapat memberi bantuan secara tidak langsung seperti obat- obatan. karena saya terlahir juga di kecamatan terangun yang memang disana populasi kerbau sangat banyak dari pada kecamatan lain karena disana masih alami bisa dibilang disana masyarakat nya belum modern jadi pemeliharaan peternakan masih banyak disana".

Campur tangan negara tentu sangat diperlukan untuk memajukan kehidupan dan nilai-nilai kebudayaan, misalnya melalui perumusan kebijakan-kebijakan. Pemerintah adalah pihak yang bertanggungjawab, karena itu, dalam menyusun setiap kebijakan, seharusnya pemerintah meletakkan kebudayaan sebagai kaca mata utama (Simatupang, 2013). 


\section{d) Pawang Kerbau / Peternak Kerbau}

Pawang adalah orang yang mempunyai keahlian istimewa yang berkaitan dengan hal-hal yang sifatnya mistis. Kemampuannya yang bisa mengetahui hal-hal yang tidak bisa diketahui oleh masyarakat awam kerap dibutuhkan dalam hal peternakan kerbau ini. Mereka biasanya berperan dalam hal mencari atau memanggil kerbau yang dilepaskan secara liar oleh pemiliknya. Sebagaimana yang disampiakan oleh Saleh Mukmin, selaku pawang kerbau, berikut ini:

"Biasanya saya melakukan pencarian kerbau liar dengan cara ritual yang saya lakukan untuk memanggil hewan tersebut seperti memanjatkan doa doa, hal ini tidak mudah dilakukan karna banyak hal yang tidak dapat kita duga akan terjadi karena berbagai kondisi"

Bahkan, seorang pawang mampu mengobati secara jarak jauh jika memang kerbau liar milik warga sedang dalam keadaan sakit. Tidak hanya itu, pawang juga berperan sebagai orang yang mampu "menjaga" kerbau yang dilepaskan secara liar itu dari serangan binatang buas lainnya. Sebagaimana pengakuan Ibrahim, yang juga berprofesi sebagai pawang, ia mengatakan bahwa:

"Hal yang perlu dilakukan disini adalah sebenarnya selain mencari kerbau liar kami juga dapat merasakan apa bila hewan tersebut sakit dan kami bisa mengobati nya dengan ilmu gaib dari kejauhan jadi hewan tersebut tidak akan mati tanpa sepengetahuan bisa dirasakan oleh pawang kerbau kondisi atau keberadaannya yang dapat membuat fatal bisa diatasi".

Kemampuan para pawang yang "berbeda" dengan kemampuan para petani kerap menjadi rujukan para peternak kerbau untuk mencari solusi terhadap segala permasalahan yang terjadi dengan kerbau mereka. Dari wawancara di atas, bisa kita simpulkan bahwa, sang pawang berperan dalam hal pencarian kerbau yang hilang, pemanggilan kerbau liar, pengobatan, dan lain-lain. Caranya dengan membacakan doa dan jampi-jampi. Meskipun dalam prakteknya ada juga peternak yang memiliki teknik tersendiri dalam hal pemulihan kerbau yang sakit. Misalnya apa yang dilakukan Kadri, ia hanya mengandangkan kerbau-kerbaunya jika memang ada yang sakit. 


\section{Analisis Peran Aktor dan Kelembagaan dalam Isu Peternakan Kerbau}

Fakta yang terjadi hari ini kita masih mendapati maraknya impor daging dari luar negeri. Ketika impor komoditas daging ini menjadi tren, tentu saja akan melahirkan beragam akibat dan dampak sebagai konsekwensi logis dari arus yang tak terbendung ini. Diskusi tentang peran stakeholder dan peran mereka dalam mengartikulasi permasalahan peternakan kerbau penting untuk dikaji, sehingga isu tersebut bisa menjadi milik publik dan mendapat perhatian secara massif. Isu peternakan kerbau tidak hanya bekaitan dengan kepentingan ekonomi masyarakat, namun juga berkorelasi dengan nilai-nilai kebudayaan yang diyakini masyarakat setempat.

Salah satu fungsi pemerintah adalah melakukan pembangunan dengan tujuan meningkatkan kesejahteraan manusia. Dalam pandangan Dudley Seers (1972), evaluasi pembangunan terfokus pada tiga kriteria ekonomi yang saling berkaitan, yaitu reduksi angka kemiskinan, pengangguran dan ketimpangan dalam sebuah masyarakat, namun dengan gencarnya tren impor daging, maka efek yang timbul bagi masyarakat peternak lokal justru sebaliknya. Dampak negatif yang hadir jauh lebih besar dan berbahaya daripada efek positifnya.

Hadi Sasana (2004) dalam jurnalnya Kegagalan Pemerintah Dalam Membangun yang mengutip Krueger (1990) mengatakan bahwa kegagalan pemerintah dapat dikelompokkan menjadi dua jenis, yaitu: omossion failures dan commision failures. Dalam penjelasannya, ia mengatakan bahwa:

“Commision failures sebagaimana yang terjadi pada BUMN yang ongkosnya mahal dan tidak efisien, ketidakefisienan dan pemborosan dalam programprogram investasi pemerintah, kontrol pemerintah yang terlalu jauh dan mahal biayanya atas aktivitas sektor swasta, maupun defisit anggaran pemerintah yang disebabkan oleh defisit BUMN dan mendorong inflasi yang tinggi dengan konsekuensi lanjutannya adalah terhadap alokasi sumber daya, perilaku tabungan maupun alokasi investasi swasta. Sedangkan failures of omossion misalnya memburuknya fasilitas transportasi dan komunikasi yang menyebabkan naiknya biaya aktivitas sektor swasta maupun sektor publik, pemeliharaan fixed nominal exchange rate berhadapan dengan Iaju inflasi yang begitu cepat yang disokong dengan exchange control dan lisensi impor, kegagalan memelihara fasilitas infrastruktur yang ada".

Berdasarkan beberapa kenyataan dan permasalahan lapangan terkait dengan isu peanganan kerbau yang telah dijelaskan, kita bisa menganalisis apa yang 
seharusnya dilakukan oleh para stakeholder terkait dalam upaya pelestarian peternakan kerbau, yaitu:

Pertama, akan masuk daging impor jika produksi daging lokal tidak mampu memenuhi kebutuhan pasar setempat. Jika ini terjadi maka keberadaan peternak lokal semakin termarjinalkan. Perkembangan usaha peternakan domestik semakin terjepit bersebab harga daging impor yang relative lebih rendah dan adanya dumping price policy oleh negara pengekspor (Priyanto, 2005). Otomatis masyarakat pun akan lebih memilih untuk membeli daging impor. Oleh karena itu, keberadaan pemerintah dalam hal ini menjadi vital. Agar kebutuhan stok daging kerbau bisa dipenuhi sesuai dengan kebutuhan pasar, maka melalui dinas terkait, pemerintah harus menggalakkan dan meningkatkan daya bangkit peternak lokal, salah satunya dengan melahirkan regulasi tentang kebijakan impor dan meningkatkan daya saing peternak lokal.

Harga produksi yang mahal yang dikeluarkan oleh petani lokal tidak memungkinkan mereka untuk bersaing dalam hal harga jual dengan komoditi daging impor, sehingga mau tidak mau daging sapi lokal kerap ditinggalkan oleh para pembeli. Karena itu, pemberian subsidi, misalnya dengan memberikan obatobatan gratis dan penyuluhan tentang dunia peternakan penting untuk dilakukan. Hal ini telah dilakukan oleh pemerintah, seperti yang diakui oleh Deddy Yopiansyah, S. ST, M.Si, selaku anggota DPRK Kabupaten Gayo Lues yang mengatakan bahwa :

"Selama saya duduk di dunia politik mendukung masyarakat baik mendukung perekonomian masyarakat saya lebih cenderung sebenarnya memberikan bantuan kepada masyarakat lebih ke bidang pertanian seperti memberi pupuk, alat penyemprot dll akan tetapi di bidang peternakan sama dengan yang lainnya juga yaitu memberi obat- obatan gratis kepada masyarakat diakibatkan banyak faktor penyakit yang terjadi pada ternak kerbau."

Kedua, segmen pasar yang terbatas. Ketika para pembeli ini mulai beralih dan memilih daging impor, sama artinya segmen pasar untuk daging lokal semakin menyempit. Sementara para peternak lokal ini tidak bisa menjual dengan harga yang murah karena memang biaya produksi yang tinggi. Efek selanjutnya yang akan muncul adalah defisit neraca perdagangan semakin melebar sehingga peternak lokal akan semakin miskin dan bahkan kehilangan lapangan pekerajaannya jika hasil produksinya tidak lagi diminati oleh masyarakat. 
Permasalahan ini juga bisa dilihat dari kacamata daya saing yang dibangun oleh Mudrajad (2005), menurut beliau, daya saing adalah kemampuan suatu produsen untuk memproduksi suatu komoditi dengan biaya minimum sehingga bisa menciptakan keuntungan pada harga-harga yang terjadi di pasar internasional. Efisien tidaknya produksi suatu komoditi yang bersifat tradeable bergantung pada daya saingnya di pasar dunia. Indikator daya saing adalah keuntungan dari pengusahaan suatu komoditi yang dilihat dari sisi privat dan sosial. Sedangkan tingkat efisiensi pengusahaan suatu komoditi dilihat dari keunggulan komparatif dan kompetitifnya.

Ketiga, Monopoli pasar oleh kaum kapitalis. Terjadinya pemusatan kekuasaan ekonomi pada kelompok tertentu, sehingga kekuatan besar yang dimiliki oleh pemilik modal bisa menentukan harga dan menentukan jumlah barang yang ditawarkan. Bahkan untuk tingkat yang lebih parah, mereka biasanya membatasi produksi pada tingkat dimana mereka bisa memperoleh keuntungan maksimum. Dengan itu, keberadaan pemerintah dengan menjamin tersedianya pasar bagi peternak lokal adalah sebuah keharusan. Intervensi pemerintah menjadi penting dalam hal balancing dunia market.

Keempat, Agen/permainan agen lokal. Kondisi ini juga ikut memperparah keadaan ekonomi para peternak lokal. Agen-agen lokal yang menjadi pembeli tangan pertama biasanya mematok harga yang relative murah dalam membeli sapi dari para peternak. Sementara mereka menjualnya dengan harga yang tinggi. Dengan power dan akses relasi yang mereka miliki, mereka bisa "menentukan" harga di pasaran. Sementara para peternak yang memelihara ternaknya bertahuntahun hanya bisa "pasrah" dalam ketidakberdayaan ketika semuanya diserahkan pada pasar. Munculnya kapitalis lokal atau para agen-agen ini disatu sisi memang bisa bermanfaat bagi para petani karena ada yang menampung ternak mereka, namun disisi lain sebenarnya mereka dirugikan ketika harga jual ditentukan oleh pasar yang tentu saja dikuasai para kapitalis lokal ini.

Dalam pandangan Bobbitt (2002), kemunculan pergeseran dari nation-state menuju market-state, di mana keberadaan bangsa dulunya untuk menjamin kesejahteraan material, untuk menyediakan keamanan ekonomi dan barang-barang public dengan memaksimalkan peluang dari semua anggota masyarakat kemudian 
berubah ke dalam bentuk privatisasi banyak aktivitas negara dan lebih membela kepentingan pasar, sehingga terkadang keberadaan pemerintah lebih kepada redistributor kapitalis.

\section{Kesimpulan}

Dari hasil penelitian tentang identifikasi stakeholders dan analisis aktor serta kelembagaan terkait isu publik pengembangan kawasan peternakan kerbau di Gayo Lues dapat diambil beberapa kesimpulan sebagai berikut:

Pertama, banyak aktor dan lembaga yang terlibat dalam usaha pengembangan peternakan kerbau di Gayo Lues. Hanya saja, kurangnya sinergitas dan kerjasama antar actor berimplikasi pada degradasi kebudayaan peternakan kerbau yang berbasis kearifan lokal, padahal praktek uwer tersebut berpotensi pada peningkatan taraf hidup masyarakat secara ekonomi dan pelestarian nilai budaya masyarakat setempat. Kedua, kurangnya stategi yang dimiliki oleh pemangku kebijakan berimplikasi pada perilaku peternakan kerbau semakin tidak dilirik saban hari. Seharusnya banyak potensi yang bisa dilihat, dikembangkangkan dan dimanfaatkan terkait praktek peternakan kerbau di Gayo Lues.

Ketiga, sistem sosial yang diperankan oleh pemerintah, peternak kerbau, tokoh adat, juga toke kerbau harus dilakukan secara maksimal sehingga bisa mencegah terjadianya economic inequality dan cultural insecurity. Dan Keempat, adanya perubahan perilaku ekonomi masyarakat setempat dalam hal system mata pencaharian, sehingga mereka kerap meninggalkan tradisi uwer dan beralih menjadi petani nilam karena dianggap lebih menjanjikan secara ekonomi. Kondisi ini seharusnya menjadi perhatian para pemangku kebijakan setempat. 


\section{Daftar Pustaka}

Affan, Heydar. 2018. Mereka Bertahan Hidup Makan Daun': Kasus kelaparan di Maluku Tengah. Diakses dari https://www.bbc.com/indonesia/indonesia44939889 pada 10-09-2019.

Amanda, Gita. 2018. Abraham Samad: Sektor Pangan Rawan Korupsi. Diakses dari https://www.msn.com/id-id/berita/nasional/abraham-samad-sektorpangan-rawan-korupsi/ar-AAvil1t pada 12-08-2019.

Anggraeni, Rina. 2013. Politik Beras Di Indonesia Pada Masa Orde Baru (1969-1998): Dari Subsistensi Swasembada Pangan Hingga Ketergantungan Impor. Skripsi pada Program Studi Pendidikan Sejarah. Bandung: Universitas Pendidikan Indonesia. Juga dapat diakses pada http://repository.upi.edu/249/

Bobbitt, P. 2002. The Shield of Achilles: War, Peace and the Course of History. London: Allen Lane/Penguin Press.

Borrows, C. W. 2000. An Exploratory study of food and beverage training in private clubs. Article on International Journal of Contemporery Hospitality Management 12, (3).p 190 -197

Kawulich, Barbara. B. 2005. Participation Observation as adata collection Methode (81 paragraphs). Forum Qualitative sozialforschung/ Forum: Qualitative Social Research, 6(2) Art. 43, diakses dari http://nbnresolving.de/urn:nbn:de:0114-fqs0502430

Kontan.co,id. 2018. Kuota impor daging kerbau di 2018 melonjak 81\% dari realisasi 2017. diakses dari https://industri.kontan.co.id/news/kuota-impor-dagingkerbau-di-2018-melonjak-81-dari-realisasi-2017

Krueger, R.A and Casey, M.A. 2000. Focus Groups: A Practical Guide For Applied Researche. $3^{\text {rd }}$ ed. Thousand Oaks: Sage

Leo, Kusuma. 2013. Sejarah Kebijakan Pangan Di Indonesia: Suatu Tinjauan. Diakses dari http://leo4kusuma.blogspot.com/2013/03/sejarah-kebijakan-pangandi-indonesia.html\#.XGYeiLgxVdg.

Madarisa, F. 2012. Potret Pasar Ternak Sumatra Barat. Jurnal Perternakan Indonesia. Vol. 14(3)

Malthus, T.R. 1798. An Essay on the Principle of Population. First Edition pertama. London: Library of Economics and Liberty. 
Mudrajad. K. 2005. Strategi Bagaimana Meraih Keunggulan Kompetitif. Jakarta: Erlangga.

Nasution, Abdullah Akhyar. 2019. Kebijakan Pangan dan Tradisi Lokal (Studi tentang Dampak Kebijakan Pengelolaan Pangan Daging terhadap Keberadaan Tradisi Uwer di Kabupaten Gayo Lues). Artikel Pada Jurnal Sosiologi UNSYIAH Vol 13, No 1 (2019). DOI: https://doi.org/10.24815/jsu.v13i1.14096

Priyanto, Dwi. 2005. Evaluasi Kebijakan Impor Daging Sapi Melalui Analisis Penawaran dan Permintaan. Dalam "Seminar Nasional Teknologi Peternakan dan Veteriner". Bogor: Balai Penelitian Ternak.

Sasana, Hadi. 2004. Kegagalan Pemerintah Dalam Membangun. Vol. 1 No.1/Juli 3138. FE UNDIP.

Seers, Dudley, 1972. What Are We Trying to Measure?. Journal of Developments Studies, 8(3). London: Frank Cass and Co.

Simatupang, Lono Lastoro. 2013. "Pengelolaan Kebudayaan: Sinergitasi Pemangku Kepentingan". Makalah disampaikan dalam Kongres Kebudayaan Indonesia pada tanggal 8-11 Oktober. Yogyakarta.

Spradley, J.P. 2007. Metode Etnografi. Yogyakarta: Tiara Wacana 